\title{
DEVELOPING SPEECH PERCEPTION SKILLS FOR BETTER LISTENING COMPREHENSION
}

\author{
Ірина БІЛЯНСБКА, кандидат педагогічних наук, асистент кафедри \\ англійської філології ДВНЗ "Прикарпатський начіональний \\ університет імені Василя Стефаника"
}

\section{ФОРМУВАННЯ СЛУХОВИХ НАВИЧОК ЯК УМОВА УСПІШНОГО АУДІЮВАННЯ}

This article provides arguments for incorporating bottom-up practice activities into listening instruction at university EFL classroom. It begins with a brief overview of the current research into listening, followed by a review of main processing components involved in speech comprehension. Also, the paper discusses Ukrainian pre-service teachers' major listening difficulties and reasons which prevent them from developing listening fluency in English. The role of the speech processor in the process of teaching listening comprehension has been determined. Psycholinguistic peculiarities of its development are discussed. It is proved that a well-developed L2 speech processor will ensure adequate perception of foreign speech and auditory self-control of one's own articulation. Activities for enriching Ukrainian university students' L2 perceptual experience (transcribing, noticing exercises) and training their L2 pronunciation (reading aloud, shadow reading) are suggested. Finally, it is concluded that improvement in speech perception makes listening process increasingly automatic, which in turn makes the development of top-down listening skills more effective.

Key words: articulation, bottom-up skills, listening fluency, listening difficulties, perception skills, pre-service teachers, speech processor.

Анотація. У статті аргументується доцільність і необхідність цілеспрямованого розвитку вмінь "знизу вгору" під час навчання студентів аудіювання іншомовних текстів. Проаналізовано сучасні дослідження у сфері аудіювання та розглянуто психічні процеси і психологічні

(C) I. Bilianska механізми, що беруть участь у сприйнятті та розумінні усного мовлення. Крім того, виявлено основні труднощі аудіювання студентів четвертого курсу та причини, що перешкоджають їм розвивати англомовну аудитивну компетентність. Визначено роль мовленнєвого слуху у процесі навчання аудіювання. Висвітлено психолінгвістичні особливості його розвитку. Доведено, що добре розвинений мовленнєвий слух забезпечить адекватне сприйняття іноземної мови та слуховий самоконтроль власної артикуляції. Запропоновано вправи для розширення перцептивного досвіду студентів (транскрибування, вправи на розвиток умінь помічати фонологічні модифікації зв'язного мовлення) та розвиток вимовних навичок (читання вголос, читання одночасно із мовцем). Зроблено висновок, що удосконалення навичок сприйняття іншомовного мовлення робить процес прослуховування все більш автоматичним, що, у свою чергу, сприяє розвитку умінь аудіювання "згори вниз".

Ключові слова: артикуляція, уміння "знизу вгору", "вільне" аудіювання, труднощі аудіювання, слухові навички, майбутні вчителі, мовленнєвий слух.

Purpose of the study. The purpose of this paper is to discuss the importance of improving students' perception skills for successful listening comprehension and identify effective techniques to target students' perceptual abilities development.

Statement of the problem. Listening skills development is one of the most important problems facing EFL pre-service teachers in Ukraine as they are expected to achieve a high level of listening competence (C1.2 - fourth-year students, C2.1-C2.2 fifth-year students $[1, p .63]$ ) in nonauthentic language environment. Lack of exposure to fast spontaneous speech and various accents of native and non-native speakers are the reasons why it is hard for students to develop listening fluency in English. Based on the results of our questionnaire given to 233 fourth-year students of 4 pedagogical universities in Ukraine (Vasyl Stefanyk Precarpathian National University, Ternopil Volodymyr Hnatiuk National Pedagogical University, Volodymyr Vynnychenko Central Ukrainian State Pedagogical University, Khmelnytsky National University) we identified 4 main factors that influenced their listening comprehension. $63 \%$ of students reported that speech rate was a major factor, $57 \%$ considered unfamiliar lexis to be the reason of their difficulties, $43 \%$ of students identified an unfamiliar accent as an obstacle to their understanding of oral speech, 37\% of them mentioned that background noise affected their comprehension. The results of the survey revealed the importance of bottom-up listening practice to help students develop better L2 speech perception, namely listening fluency in English.

Research overview. Recent research has demonstrated a strong interest of scholars into L2 listening. Various psycholinguistic issues of listening, in particular, auditory processes underlying speech understanding, are explored by such scientists as A. Anderson, R. Cauldwell, R. Fitch, Ch. Goh, S. Greenberg, A. Ilner, L. Kulish, S. Miller, J. Richards, M. Rost, J. Rubin, P. Tallal, L. Vandergrift, A. Wolvin, I. Zymnja. A. Ilner researched the role of the speech processor in foreign language learning. Much research has been done into top-down and bottom-up processing in L2 listening (M. Celce-Murcia, J. Field, G. Jiang, A. Libert, C. Moskovsky, E. Olshtain, J. Richards), bottom-up processing difficulties (S. Brown, J. Siegel, L. 
Vandergrift, M. Wilson). EFL methodologists also study benefits of extensive and intensive listening (M. Apple, E. Bozan, H. Brown, M. Ediger, D. Ewert, T. Farrell, J. Harmer, W. Holden III, C. Goh, S. Millet, N. Northall, M. Pilott, W.Renandya, M. Rost, B. Sheppard, L. Vandergrift, R. Waring), listening journals (C. Chen, J. Harmer, A. Schmidt), listening strategies (N. Anderson, J. Field, X.Henderson, L. Vandergrift), authentic materials (D. Brown, J. Ross, A.McDonald). Contemporary EFL researchers even develop methodologies aimed at acquainting students with different varieties of English (V. Lapina, O.Matsnyeva, M. Yevdokimova). A variety of recent research into listening comprehension provides a basis for more effective listening instruction at university EFL classroom.

Results and discussion of the research. Any language at the acoustic level is represented by the perceptual and articulatory bases. The perceptual basis is a system of perceptual models of speech units and specific correlation rules which are kept in one's memory [3, p. 62]. The articulatory basis is the system of articulatory models of speech units and speech motor skills, a set of common movements and places of speech organs during articulation. These two bases of a language improve in the process of its mastering. A perfectly-developed articulatory basis gives an opportunity to follow pronunciation norms and models of a language. A perfectly-developed perceptual basis of a person is determined when he/she can capture those deviations in speech which are considered violations. However, as A. O. Ilner contends, the perceptual basis develops faster than the articulatory one $[3, p$. 63]. It is obvious that proper L2 perceptual and articulatory basis development in a non-authentic learning environment is a great challenge and should be addressed with an efficient methodological approach, various authentic listening materials, ubiquitous environment which supports learning anytime and anywhere through modern technological devices [10]. Therefore, psycholinguistic peculiarities which affect adult learners' foreign language learning experience should be examined in greater detail.

According to scientists, any person is born capable of learning any language. However, exposure to speech during childhood alters neural organization in the brain so that individuals develop perceptual and cognitive processes that are specialized for their own native language. As a result, adult L2 learners experience perceptual difficulties with any L2 sounds that are not similar to those in their L1 [8, p. 39]. In order to manage foreign speech in real time and reconstruct the meaning of utterances, non-native listeners should be able to make use of the available acoustic information. Thus, on the basis of the existing perceptual bases the speech processor forms a new one which goes through several consecutive stages of its improvement in the process of learning a foreign language $[3, p .72]$. Empirical research identified 3 levels of the perceptual basis development judging by one's ability to recognize and perceive speech reliably (sufficient development $(60 \%)$, insufficient development $(35 \%)$, undeveloped perceptual basis (less than $35 \%)$ ) [3, p. 73].

One of the main psychological mechanisms for oral speech perception in both L1 and L2 is the speech processor which is defined by scientists as the ability to hear and analyze the speech sounds of a native or foreign language by distinguishing them and combining them with relevant model units of segmental and suprasegmental levels which are stored in a person's long-term memory $[3, p .6]$. This speech processor forms and develops during one's lifetime in a specific language environment and by its laws, with the help of which a person can perceive and evaluate speech of others and is able to control one's own articulation [3, p. 10]. The indication of a perfectly developed L2 speech processor is the ability of a non-native speaker to discriminate the same phonetic features which are discriminated by native speakers [3, $p$. 61]. Speech processing researchers point out that phonetic feature detectors in the auditory cortex, which enable the listener to encode speech into linguistic units, atrophy during their development if they are not used, that's why adults eventually retain only the phonetic feature detectors that were stimulated by their native language $[8, p$. 39].

While mastering a foreign language outside authentic environment, an adult person has to re-form the speech processor which is adapted for his/her native language. Phonetic interference plays an important part in one's learning process manifesting itself both during speech perception and its production [3, p. 44]. The development of the speech processor will ensure not only adequate perception of foreign speech, but also auditory self-control and correction of one's own articulation $[3, p$. 70]. Therefore, the essential role of a well-developed L2 speech processor in foreign language learning prompts us to examine effective ways of its training during extensive and intensive listening practice of various materials at university EFL classroom.

Listening is a complex skill involving such cognitive processes: 1) top-down and bottom-up processing; 2) controlled and automatic processing; 3) perception, parsing, utilization; 4) metacognition, which are interrelated in automatic listening comprehension [9, p. 17]. R. Cauldwell emphasizes that perception is a key skill that is a pre-requisite for understanding speech [5, p. 4]. However, it should be pointed out that in a traditional communicative EFL classroom in Ukraine, listening instruction is focused mainly on the development of top-down listening skills, in particular, listening for global understanding, listening for details and selective listening. The classic listening procedure includes such stages as activating students' prior knowledge, listening to a short audio recording and verifying students' responses. This approach in listening comprehension methodology is called the comprehension approach $[6, p .4]$. It is criticized by many researchers. L. Vandergrift and K. Goh emphasize that such a listening procedure is more like testing students rather than teaching them to listen more effectively $[9, p .4]$. Therefore, they recommend developing students' metacognitive awareness of L2 listening processes and activities which would be aimed at training their bottom-up skills.

The current trend in the teaching of listening is an approach that combines the development of top-down and bottom-up skills. The attention to bottom-up skills of contemporary methodologists is linked to the phonetic difficulties of connected English speech (reduced forms of words, elision, assimilation, resyllabification (liason), linking etc.) faced by non-native speakers. As information processing is based on the skills of its perceptual processing [2, p. 101], it is necessary to target students' perceptual abilities by means of different bottom-up activities and prepare them to cope with fast spontaneous English speech under realistic conditions. Students should be offered to do intensive in-class and out-of-class listening practice, work with transcripts of various recordings and do some noticing exercises, paying attention to phonological modifications of the English speech. To train students to observe features of connected speech, we suggest the following task:

Task. Read and listen to the following passage from the short story "Black Vodka" by D. Levy simultaneously. Pay attention to word-linking, pronunciation of auxiliary verbs, pauses, intonation and stress. Try to spot different phonological processes 
which occur in fast speech. Use the text transcript to mark these features.

The importance of improving speech perception skills is also related to the role of vocabulary, which, according to empirical studies of scholars, is one of the main factors for successful listening (50\%). Scientists point out that students very often do not recognize familiar words in connected speech and this proves their inability to segment the speech stream into units $[9, p$. 271]. M. Rost defines segmentation as "the problem of locating word boundaries in a continuous signal in which physical cues are rarely present". English is a stress-timed language and $90 \%$ of all content words in English have stress on the first syllable, so listeners can use stress as an indicator of the start of a new word. Another problem they face in decoding speech is variation or "sloppy" articulation [8, p. 36]. The skills of word recognition and speech segmentation are also closely connected with the perception of speech rate $[9, p$. 271]. A slow or moderate rate of speech may seem quick due to the inability of a listener to recognize and segment familiar words in connected speech. Scientists state that the slow rate of English speech is 120 130 words per minute, the average rate is 150 words per minute $[1, p .75]$. However, M. Rost points out that the normal speaking speed for native speakers is considered to be 180 words per minute [ 8 , p. 52].

It is also known that recognition of words and speech decoding can fail under real-world conditions if acoustic interference occurs. According to researchers, even computer speech recognition systems, capable of recognizing complex linguistic material, do not perform well under such circumstances. S. Greenberg concludes that background noise or reverberation reduces the word-level accuracy to $20-50 \%[7, p$. 63]. This should be taken into account by the teachers who teach listening comprehension. It is advisable to provide students with appropriate listening atmosphere and eliminate any disturbing background noise. Also, the quality of listening materials, which are chosen for teaching listening skills, should be analyzed.

L. Yu. Kulish outlined the following characteristics of oral speech: diction, intelligibility, emotionality, loudness or voice register, accentuation, basic tone, peculiarities of word pronunciation, speech defects, and speech tempo [4, p. 82]. The scientist concluded that it is difficult to perceive speech if its parameters have at least two negative characteristics, such as almost complete absence of logical stresses and low volume $[4, p .83]$. Therefore, it is important to consider the effect of any acoustic interference on listening results and the quality of recordings. Nevertheless, purposeful and systematic practice of students is needed to ensure the development of their ability to recognize and segment words in connected speech under realistic conditions, in new contexts, spoken by different speakers with various accents and at different speech rates. As listening in foreign language becomes increasingly automatic with practice $[9, p$. 41], students should be advised to do a lot of extensive listening to various types of input outside classroom.

The main component of the speech perception is phonemic perception [3, $p$. 14]. The phonemic speech processor enables listeners to distinguish phonemes of a language $[3, p .12]$. At the traditional university EFL classroom in Ukraine the technique which is still used to develop students' phonemic perception is the use of minimal-pair drills and perception exercises at the sentence level, which are often decontextualized. Therefore, such scholars as L. Vandergrift and K. Goh recommend developing bottom-up skills using various texts. After top-down listening to a text at the post-listening stage when students are no longer under pressure to understand the recording, they should be given an opportunity to concentrate on the phonological processes of connected English speech, noticing its various features (weak forms, rhythm, word and sentence stress, rise in tone, pauses, linking etc.) [9, p. 272].

Audio materials reflecting various English accents will contribute to the development of students' phonemic perception, their adaptation to different types of normative and non-normative pronunciation. For authentic listening practice, we recommend fiction audiobooks (contemporary short stories or novels) which are narrated by professional voice actors who skillfully render social, regional or national peculiarities of various characters. Also, listening to non-fiction audiobooks, interviews, podcasts or watching to Youtube videos would be good practice. Students should be offered to transcribe extracts of recordings or videos. Transcribing exercises are difficult for students, however, the recognition of words will be facilitated by the context and such psychological listening mechanisms as apperception (reliance on past experience) and anticipation (probabilistic forecasting). As noted by researchers, context is the most important cue for rapid word recognition [9, p. 159]. Meaningful bottom-up listening exercises may be offered to students on the basis of a short story. For example:

Task. Listen to an extract from the short story "Prepositions" by L. Shriver, read by an American narrator. Make a transcript of it.

Taking into account the fact that the speech processor develops under the influence of correct articulation [3, p. 65], it is important to offer students exercises for improving their articulatory skills. Imperfect articulatory basis of a person is the main reason for one's foreign accent $[3$, p. 63]. It is also known that a person cannot control all parts of one's articulatory apparatus consciously, so auditory control of one's articulation is provided by the speech processor $[3, p$. 65]. To train their foreign language pronunciation and intonation, students should use transcripts of recordings and practice reading aloud or reading along with a speaker of the recording (shadow reading) trying to mimic them. For example:

Task 1. Listen to a passage from the short story "Even Pretty Eyes Commit Crimes" by M.J. Hyland. Use the text transcript to mark the main stresses and intonation in the sentences. Practise reading the text aloud.

Task 2. Listen to a passage from the short story "The Human Circadian Pacemaker" by K.J. Orr. Use the text transcript to mark the main stresses and intonation in the sentences. Play the audio again and this time read along with the speaker trying to mimic their intonation as much as possible. Finally, practise reading the text aloud without the audio.

Students should work hard to automatize their L2 pronunciation skills. However, non-authentic language environment can cause rapid deautomatization of one's articulatory skills. Thus, such practice should be systematic.

It was long been believed that musically talented people are better at learning foreign languages. However, researchers prove there is no direct connection between these abilities. They differentiate between a person's physical ability to perceive sounds and the ability to perceive speech. As a result, speech perception is opposed to non-speech perception which is defined as the ability to distinguish non-speech sounds (for example, musical and noise sounds) [3, p. 9]. Although speech and non-speech types of perception are both based on auditory perception, different psychophysical mechanisms underlie them [3, p. 23].

Research into such disorders as amusia (musical disorders) and sensory aphasia (disorders in phonemic perception) clearly 
demonstrates that a person can preserve some abilities but lose others. A. Luria described cases when people with a phonological awareness deficit preserved their musical ability [3, p. 22]. A. O. Ilner concludes that there is no direct relationship between musical abilities of a person and the ability to study foreign languages. The speech processor develops during one's lifetime in a specific language environment but perfect pitch is congenital and cannot be developed. However, relative pitch can still be developed. A. O. Ilner adds that some components of speech perception are indirectly connected with non-speech perception, for example, intonation perception. Those who are musically talented or those who train their musical abilities perceive intonation models of a foreign language like musical patterns. As a result, the experience of musical ear and voice training has positive influence on foreign speech perception and production. However, they still experience phonetic interference (the influence of L1 on L2) while mastering a language in non-authentic environment [3, p. 23].

Conclusions. The findings of the current study demonstrate strong interest of EFL methodologists in the development of learners' perception skills through activities which encourage bottom-up processing. Bottom-up language processing is considered to be a tool which facilitates listeners to achieve the goal of comprehension. Perception skills are proved to be a pre-requisite for understanding. It is also revealed that particular attention should be paid to the development of the speech processor as it enables a person not only to perceive speech of others but also control one's own articulation. Therefore, listening instruction at university classroom should combine top-down and bottom-up listening practice, teaching of listening and pronunciation. Such activities as transcribing, noticing, reading aloud and shadow reading should be encouraged since they can ensure not only improvement of perception skills but also students' articulation. Students should be trained to cope with the variability of spoken speech and observe its features by means of various authentic materials. A welldeveloped L2 perceptual basis will help them eliminate potential phonological difficulties during listening, which in turn will contribute to successful development of their top-down listening skills.

Directions for future research. As a result of the use of English as a lingua franca, the issue of teaching different varieties of English is becoming an increasingly promising field for research. Pre-service English teachers as participants of intercultural communication should not only be aware of such varieties but also develop the ability to deal with such varieties receptively.

\section{ЛІТЕРАТУРА}

1. Задорожна I. П. Теоретико-методичні засади організації самостійної роботи майбутніх учителів з оволодіння англомовною комунікативною компетенцією: дис. ...д-рапед. наук: 13.00.02. Київ, $2012.770 \mathrm{c}$.

2. Златніков В. Г. Методика навчання професійно орієнтованого аудіювання англійською мовою курсантів вищих військових навчальних закладів: дис. .... канд. пед. наук : 13.00 .02 . Київ, 2012.230 с.

3. Ильнер А. О. Развитие иноязычного речевого слуха в условиях учебного многоязычия: монография. Екатеринбург: УрФУ. 2016. 136 с.

4. Сіваченко О. О. Навчання аудіювання англомовних драматичних творів студентів старших курсів мовних спеціальностей: дис. ...канд. пед. наук: 13.00.02. Київ, 2009. 284 с.

5. Cauldwell R. Grasping the nettle: The importance of perception work in listening comprehension.

URL: www.developingteachers.com/ a r i c l e s_t c h t r a i n i g / perception1_richard.htm (Last accessed: 18.04.2019).

6. Goh C. C. A special issue on second and foreign language listening pedagogy and assessment. International Journal of Innovation in English Language teaching and Research [Editorial]. 2014. 3(2). P. 113-119.

7. Greenberg S. Understanding speech understanding: towards a unified theory of speech perception. URL: https:// pdfs.semanticscholar.org/c 3 f5/ bc52be98338d72af3218244aae

6f9e 2b5ce5.pdf (Last accessed: 18.04.2019).

8. Rost M. Teaching and Researching Listening. Second edition. Pearson Education Limited, 2011. 407 p.

9. Vandegrift L., Goh Ch. C. M. Teaching and Learning Second Language Listening. Metacognition in action. New York, London: Routledge, 2012.315 p.

10. What is Ubiquitous Environment. IGI Global. URL: https://www.igiglobal.com/dictionary/universities-pointof-view-to-introduce-mobile-devices-intheir-classrooms/55570 (Last accessed: 18.04.2019).

https://www.igi-global.com/dictionary/ universities-point-of-view-to-introducemobile-devices-in-their-classrooms $/ 55570$

\section{REFERENCES}

1. Zadorozhna I. P. Teoretykometodychni zasady orhanizatsii samostiinoi roboty maibutnikh uchyteliv z ovolodinnia anhlomovnoiu komunikatyvnoiu kompetentsiieiu: dys. ... d-ra ped. nauk: 13.00.02 / Kyivskyi nats. linhv. un-t. Kyiv, $2012.770 \mathrm{~s}$.

2. Zlatnikov V. H. Metodyka navchannia profesiino oriientovanoho audiiuvannia anhliiskoiu movoiu kursantiv vyshchykh viiskovykh navchalnykh zakladiv: dys. ... kand. ped. nauk: 13.00 .02 / Kyivskyi nats. ped. un-t im. Tarasa Shevchenka. Kyiv, 2012.230 s.

3. Iner A. O. Razvitie inoyazychnogo rechevogo slukha v usloviyakh uchebnogo mnogoyazychiya: monografiya. Ekaterinburg: UrFU. 2016. 136 s.

4. Sivachenko O. O. Navchannia audiiuvannia anhlomovnykh dramatychnykh tvoriv studentiv starshykh kursiv movnykh spetsialnostei: dys. ... kand. ped. nauk: 13.00.02 / Kyivskyi nats. linhv. un-t. Kyiv, 2009. 284 s. 205.

5. Cauldwell R. Grasping the nettle: The importance of perception work in listening comprehension. URL: www.developingteachers.com/

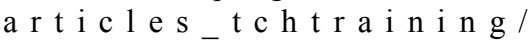
perception1_richard.htm (Last accessed: 18.04.2019).

6. Goh C. C. A special issue on second and foreign language listening pedagogy and assessment. International Journal of Innovation in English Language teaching and Research [Editorial]. 2014. 3(2). P. 113-119.

7. Greenberg S. Understanding speech understanding: towards a unified theory of speech perception. URL: https:// pdfs.semanticscholar.org/c 3 f5/ bc52be98338d72af3218244aae6f9e2b5ce5.pdf (Last accessed: 18.04.2019).

8. Rost $\mathrm{M}$. Teaching and Researching Listening. Second edition. Pearson Education Limited, 2011.407 p.

9. Vandegrift L., Goh Ch. C. M. Teaching and Learning Second Language Listening. Metacognition in action. New York, London: Routledge, 2012.315 p.

10. What is Ubiquitous Environment. IGI Global. URL: https://www.igiglobal.com/dictionary/universities-pointof-view-to-introduce-mobile-devices-intheir-classrooms/55570 (Last accessed: 18.04.2019).

Стаття надійшла 18.03.2019 p. 